\title{
Targeting Escalation of Intimate Partner Violence: Evidence from 52,000 Offenders
}

\author{
Lee Barnham ${ }^{1}$ - Geoffrey C. Barnes ${ }^{2}$. \\ Lawrence W. Sherman ${ }^{3}$
}

Published online: 31 July 2017

(C) The Author(s) 2017. This article is an open access publication

\begin{abstract}
Research Question Does the severity or frequency of intimate partner violence or abuse reported to police increase over time, once a unique perpetrator-victim couple has come into contact with police in Thames Valley, UK?

Data A total of 140,998 recent (non-historical) incidents of intimate partner violence or abuse reported to Thames Valley Police in 2010-2015 were identified, with 52,296 unique perpetrators for whom a standard 731-day observation period was possible after each perpetrator's first incident was reported in the intake period from 1 January 2010 through 31 December. Duplicate entries were eliminated and standard eligibility criteria were assured by data cleaning from the NICHE records management system of Thames Valley Police.

Methods All non-crime incidents or reports of crime against intimate partners were coded by the Cambridge Crime Harm Index (CHI) with the sum of total days of recommended imprisonment for each offence (as the guideline starting point for sentencing) summed across all offences for each offender (Sherman et al. in Policing, 10(3), 171-183, 2016), with CHI scores for each successive incident plotted in sequence. Prevalence and frequency of repeat police contacts were also computed for each perpetrator, as well as the conditional probability of each new offence given the number of prior offences.

Findings Most perpetrators identified in the 52,296 initial reports (77.6\%) had no report of crime after the initial report. A further $21.2 \%$ had crime harm totals of less than 10 days of recommended prison time, with only $893(1.7 \%)$ of the total universe of 4 years' worth of perpetrators who had a reported crime harm total over offences with a
\end{abstract}

Lawrence W. Sherman

Lawrence.Sherman@crim.cam.ac.uk

1 Thames Valley Police, Kidlington, Oxon, UK

2 Western Australia Police, Perth, Australia

3 Institute of Criminology, University of Cambridge, Cambridge, UK 
recommendation of over 10 days sentencing in the 731-day observation period. A slightly larger 'power few' of $3 \%$ of perpetrators accounted for $90 \%$ of total intimate partner abuse crime harm inflicted by all perpetrators, while $97 \%$ of perpetrators produced only $10 \%$ of total crime harm. Overall, amongst the few who had numerous repeat incidents, there was increasing frequency but no evidence of increasing seriousness of harm caused to victims. The 100 most harmful offenders in 2010 maintained a high (but greatly decreased) level of harm in 2011, but on average were very low harm offenders in 2012-2015.

Conclusions This analysis suggests that the intimate partner abuser population is highly segmented in Thames Valley, with a small power few inflicting most of the harm. While the most serious offenders may remain difficult to identify prospectively, any valid prediction model could help to prevent a substantial amount of crime harm against intimate partners. Investing in such prediction methods may do more to help victims than an undifferentiated strategy putting most resources into low-risk cases.

Keywords Intimate partner violence $\cdot$ Policing $\cdot$ Crime Harm Index $\cdot$ Forecasting high harm

\section{Introduction}

\section{Targeting Escalation in Intimate Partner Violence}

In a widely publicised national report, Her Majesty's Inspectorate of Constabulary (Her Majesty's Inspectorate of Constabulary 2014) called on the police service to do more to systematically target repeat and prolific perpetrators of domestic abuse to reduce victimisation. It recommended that police forces make use of techniques applied to reduce other types of offending as well as multi-agency work used in integrated offender management (IOM). This recommendation, however, was based on an untested assumption: that victims suffer most harm from offenders committing the highest number of offences, without consideration of how much harm they each inflict. All domestic abuse is not created equal; it varies enormously in severity across offenders. The conflation of frequency vs. seriousness of offending is a common flaw in discussing crime 'risk' in the UK, as elsewhere. Whether or how much the two dimensions overlap is not a matter for assumptions, but a question for empirical research by police and scholars.

This article addresses that question by analysing 140,998 incidents of partner abuse reported to Thames Valley Police (TVP) between 2010 and 2015. TVP is the largest non-metropolitan police force in England and Wales covering the counties of Berkshire, Buckinghamshire and Oxfordshire. The research provides a comparison of frequency of abuse between partners vs. the level of harm inflicted and tracks average crime harm caused by re-offending across a 731-day observation period after initial reports about 52,296 perpetrators. This is followed by a detailed examination of the issue of escalation in the severity and frequency of harm caused by re-offending in two ways: firstly, by analysing what happens to the most harmful 50, 100 and 500 perpetrators from 2010 in the years that follow and, secondly, by examining all reoffending using a fixed 2-year follow-up period from the first incident in the dataset. 
The primary research question for this article is whether intimate partner abuse escalates over time, in severity, frequency or both. The primary limitation this article has in answering that question is that most cases of domestic abuse are not reported to police. Thus, all the answers this article provides are subject to the reporting biases built into couples, families, households and communities. We must keep in mind the challenge free society faces by maintaining valued institutions of privacy that prevent both police and scholars from directly measuring unreported domestic violence. Yet that proviso notwithstanding, there is much to be learned from analysing police records, especially using key concepts in evidence-based policing.

The Cambridge Crime Harm Index (CHI) provides a consistent, if crude, measurement of variations in harm suffered from case to case by applying the Sentencing Guidelines of England and Wales (Sherman et al. 2014, 2016). These guidelines are not intended to reflect the subjective experience of each victim, nor to appreciate all of the different kinds of harm domestic abuse can cause to families, children, employers and society. The Cambridge CHI is a value ascribed to each type of crime using the sentencing guidelines for a first-time offender, allowing reliable and precise distinctions between the severity of offences to be made on the basis of a consensus of judges, public opinion experts and others-under a procedure established by an elected Government that gives them the force of law.

This article begins by reviewing current knowledge about the extent of partner abuse re-offending and the challenges faced by agencies, such as the police, in operationalising the findings. In particular, the review considers how more recent research calls into question previously accepted theory that partner abuse is nearly always repeated and gets worse. The chapter concludes with a critical assessment of attempts to develop a meaningful and sustainable way of measuring the severity of harm between different types of offences.

The next section explains the methodology used in this research, including a description of the nature and quality of the data analysed. The findings show that while most domestic abusers reported to police commit no domestic crimes for at least 2 years, a few who do commit more crimes do so with escalating frequency. The seriousness of their crimes, however, does not escalate over time, even in that small subset. Thus, the article falsifies the hypothesis that most offenders escalate in both frequency and seriousness.

\section{Claims and Facts About Escalation in Intimate Violence}

Claim: Most Abused Victims Suffer Repeated Offending It is widely accepted (but largely untested) within policing in England and Wales that by the time a victim makes a report to the police, they have invariably experienced a pattern of abuse (Richards et al. 2008). This view is well illustrated by the frequently cited claim that those victims who report an incident of domestic abuse to the police in England and Wales will have already suffered an average of 35 unreported incidents. However, the veracity of this claim has been challenged by Strang et al. (2014), who traced the origins of this figure to research carried out in 1979 in a small Canadian city. The number 35 was calculated on the basis of just 53 interviews with women who said they had been the victim of a prior incident before the police became involved. The results also excluded data from 15 interviews where the victims did not report any prior incidents preceding police 
involvement. As such, the study suffers from both low statistical power (with a response rate of just $24 \%$ on a sample size of 222 victims) and a lack of external validity (Strang et al. 2014).

The claim about extensive prior abuse is also challenged by the annual Crime Survey of England and Wales (CSEW). This survey asks respondents about the number of times they have experienced violent and non-violent abuse from an intimate partner. Over 12 months ending in March 2015, 14\% of men and 16\% of women said they had suffered abuse by their partner more than once. However, these figures need to be treated with some caution because $70 \%$ of respondents either said they did not know or refused to give an answer. A subset of respondents was asked further questions about the number of victimisations they had suffered from their partner. The results show $70 \%$ suffered one victimisation, $14 \%$ of victims experienced two victimisations and $16 \%$ experienced three or more incidents of violent or non-violent abuse. Repeat victims were found to have experienced $60 \%$ of all incidents (ONS 2016).

Using 36,000 police records of all domestic abuse (not just between intimate partners, but including family members such as siblings or parent-child abuse) reported to Suffolk Constabulary, Bland and Ariel (2015) found the majority of 'dyads' (76\%) made only one report over a 6-year open observation period. A smaller number of victims, just $11 \%$, reported suffering three or more incidents.

Claim: Repeated Intimate Abuse Escalates in Frequency and Intensity This claim has been widely accepted since Pagelow (1981) asserted "one of the few things about which almost all researchers agree is that batterings escalate in frequency and intensity over time" (p. 45). A slightly different version of escalation in partner abuse indicates that relationships follow a cyclical pattern. Walker (2006) conducted interviews in the late 1970 s with women who had been assaulted by their partners and identified a threephase pattern which followed initial courtship. In the first phase, known as 'tension building', women said their partners became increasingly verbally abusive and tried to socially isolate them. In response, the women described trying to appease their partners. However, despite their efforts to keep the situation clam, the tension continued to build leading to the 'battering' phase characterised by physical assault. Walker (2006) found such violence could be a single episode or last for days or even weeks. The third phase is marked by a period of 'contrition' where the perpetrator seeks forgiveness.

Other studies have reported a far more complicated picture of escalation in severity. Piquero et al. (2006) used victim interview data from the Minneapolis Domestic Violence Experiment as well as replications of the study to examine escalation in violence against the same victim. Escalation was measured by comparing the level of injury reported at the point police intervened (and either made an arrest, separated the couple or offered advice) with new assaults reported in subsequent interviews.

Piquero et al. (2006) found evidence of groups whose offending escalated and deescalated as well as individuals who perpetrated both stable low-level aggression and consistently high levels of aggression. Piquero et al. (2006) concluded that not all men escalate their abuse, but suggest that men who are most severely violent initially are likely to continue their violence over time. However, the research is limited by missing survey data, low response rates and a focus on less serious assaults where the police could use discretion in their response. Nevertheless, the research challenges established 
views on escalation while highlighting the need for further longitudinal research. This thesis will be a direct contribution to this identified need.

In their study of police data from Suffolk, Bland and Ariel (2015) did not find any evidence for statistically significant escalation in the severity of harm inflicted against victims of all domestic abuse. Using a crime harm index to attach a numerical score to the degree of harm caused by each offence (described in more detail below), the authors were able to measure any escalation in the severity of offending. While analysis of the first 10 calls made by a victim to the police showed an upward trend of escalating harm, this was due to the high levels of harm present for those experiencing more than three events. Because most dyads did not experience any repeat incidents (let alone three), Bland and Ariel (2015) argue that the majority of couples do not experience escalation in levels of harm. Amongst the 76 couples who experienced $80 \%$ of all harm, Bland and Ariel (2015) did not find any evidence of consistency in escalation over the course of each subsequent event. However, as the authors acknowledge themselves, this represents a low proportion of dyads and is a small sample for trajectory analysis (Bland and Ariel 2015). Their findings add further evidence against the claim that abuse always gets worse.

Measuring Partner Abuse with the Concept of Harm The idea of escalating severity may be best captured with the concept of 'harm'. This is an old idea in criminology, developed as a more meaningful way of reporting crime than traditional counts of all crime types given equal weight. Early efforts by Sellin and Wolfgang (1964) and Wolfgang et al. (1985) to measure harm by public opinion, however, were severely limited by the method of 'rank ordering,' which does not distinguish how much more serious (or harmful) one offence is over another (see also Ignatans and Pease 2016).

Equally problematic are estimates of the average financial costs of individual crime types which require annual readjustment (Ratcliffe 2015; Sherman et al. 2014). In England and Wales, Dubourg and Hamed (2005) calculated the costs of each crime type according to the physical and emotional consequences to the individual as well as the costs to a range of public services. These calculations are so complex that costs are provided for very broad offence categories that do not take account of the variations between crime types (Ratcliffe 2015; Sherman et al. 2014).

This last point has been addressed by scholars who have used actual court sentencing as a metric for an index. In Canada, a Crime Severity Index was developed with each offence being assigned a seriousness 'weight' determined by the actual sentence handed down by the court (Wallace et al. 2009). This method, however, also fails to provide a consistent baseline. Sentencing is a more complicated decision made on the basis of a number of factors, including the prior conviction history of the defendant, point at which they were convicted and any mitigation, rather than the harm caused by the offence (Sherman et al. 2016).

Ratcliffe (2015) proposed the use of offence gravity scores provided to judges across Pennsylvania. This method is independent of the police and allows the weighting of specific categories of offence. However, Ratcliffe's (2015) proposal is based on a very narrow score ranging from 1 for a misdemeanour to 14 for murder. This ordinal scale does not address the need to have a consistent ratio that measures the many small differences in harm between and across hundreds of different offences. 
Sherman et al. $(2014,2016)$ propose an alternative method, using an index based on the sentencing starting point for any offender convicted for the first time. Each offence is given a value equivalent to the number of days imprisonment imposed on offenders with no prior criminal history, and no mitigating or aggravating circumstances in the crime at hand. This method is called the Cambridge Crime Harm Index (CHI). Using the sentencing starting point has the advantage of avoiding the consideration of other factors when sentencing. However, Ignatans and Pease (2016) argue this approach is limited in that it removes judgements about severity from the victims of crime. Because the guidelines are prepared by a group of experts with experience of higher courts and detected crimes, Ignatans and Pease (2016) suggest that sentence starting points might not be a true reflection of harm as victims see it.

Nevertheless, the Cambridge $\mathrm{CHI}$ is the only method capable of being translated into practice quickly and at no cost. The Cambridge $\mathrm{CHI}$ is democratic in the sense that UK Parliament passes the decision on sentencing guidelines to a Council of judges and other experts (Sherman et al. 2016). In applying the Cambridge CHI, the reported levels of harm are based on an objective measure using a consistent ratio that measures the difference in harm between the various offences.

\section{Data}

Data for this study was taken from NICHE police records system covering the period 1 January 2010-1 January 2016. In total, there were 192,173 incidents contained within the initial dataset. These data were collected with substantial procedural checking Thames Valley Police (TVP) have in place for the systematic collection and auditing of information, particularly in dealing with reports of domestic abuse.

This systematic data collection for incidents of domestic abuse begins at the point of a call for service. Although calls to TVP are initially logged in a different system known as 'Command and Control', an officer must attend every report of domestic abuse in person to ascertain what happened, who was involved and complete a risk assessment whether a crime has been reported or not. Even before an officer attends a skeletal NICHE report is generated and flagged as domestic abuse. This flag can be used as a search criterion to allow for the extraction of incidents specifically identified as cases of domestic abuse. After an officer has attended, further information is relayed to a police enquiry centre to finalise the NICHE report. If there is a crime, the appropriate offence is recorded. However, if there is not a crime, a NICHE record is still completed and classified as non-recordable incident. The content of these 'non-crime' incidents mirrors the information included in incidents recorded as a crime. As well as helping to ensure cases of domestic abuse are recorded consistently and ethically, this means TVP hold a large amount of data concerning domestic abuse in one system.

NICHE reports also undergo a review by police supervisors and subsequently a team of auditors to ensure compliance with the National Crime Recording Standards (NCRS) and Home Office Counting Rules (HOCR). The NCRS is victim focussed and seeks consistency in recording across police forces in England and Wales by applying legal definitions of crime to reports made. The HOCR specifies what type and how many 
offences should be recorded by the police for each incident. These procedures ensure there is a universal standard to the recording of crime in England and Wales.

\section{Key Definitions: Partner Abuse}

The specific definition of partner abuse used in this research is as follows:

Any incident or pattern of incidents of controlling, coercive, threatening behaviour, violence or abuse between those aged 18 or over who are, or have been, intimate partners regardless of gender or sexuality. The abuse can encompass, but is not limited to psychological, physical, sexual, financial and emotional. (Home Office definition [adapted], 2013).

This definition follows the UK cross-government classification of domestic abuse ${ }^{1}$ but excludes abuse between non-intimate family members. Although more narrowly focused, it captures a wide pattern of behaviour associated with incidents of partner abuse whether they are criminal or non-criminal. Across the period 1 January 2010-1st January 2016, a total of 235,918 incidents of domestic abuse (including non-intimate family members) were recorded by TVP. Of these incidents, 162,258 (68\%) were classified as cases involving intimate partners.

The UK cross government definition changed in 2012 to include those aged 16 and 17 years. In order to ensure the analysis is consistent, any incidents where the victim or perpetrator was under 18 years were excluded from the data extracted from the crime recording system.

\section{Definition: Victim and Suspect}

The TVP crime recording system requires that every individual listed in a NICHE report is assigned a role. Although an individual can be assigned more than one role, for the purposes of this research, the important designations are 'victim' and 'suspect'. These terms are common parlance in policing and distinguish between the person who appears to have suffered some form of harm (victim) and the person responsible for causing harm (suspect). While the status of suspect does not imply guilt, using recorded offences as the measure of offending and recidivism avoids more conservative estimates of actual behaviour implicit in measures that use charges or convictions (Hanson et al. 2014). Very few cases of domestic abuse result in a prosecution so relying on convictions would eliminate a large number of incidents. Excluding these cases would almost certainly bias the results because prosecuted cases (let alone those leading to conviction) are likely to be quite different from those that are not.

Definition: Repeat Offending In this research, the definition of a repeat offender is an individual identified as a suspect in two or more incidents, whether this amounts to a criminal offence or not. In this research where the 2-year follow-up period is used, a

\footnotetext{
${ }^{1}$ This definition changed in 2012 to include 16- and 17-year-olds. The new definition also makes explicit reference to patterns of controlling, coercive or threatening behaviour. An offence of coercive control was created in 2015 but not enforceable until 31 December 2015.
} 
repeat offence (if there is one) is identified using a period of 2 years (731 days) from the date of the first incident appearing in the dataset. ${ }^{2}$ Although it could be argued that this follow-up period is limited, especially where a perpetrator is given a long sentence of imprisonment, it is worth noting that of all domestic abuse incidents reported to TVP between 1 May 2015 and 30 April 2016, just $7 \%$ of cases were prosecuted by charging the perpetrator to court. ${ }^{3}$ Data from the Crown Prosecution Service ${ }^{4}$ (2016) shows that of all domestic abuse cases sent to court in England and Wales in the financial year 2014$2015,26 \%$ did not result in conviction. As such hardly any perpetrators will have been imprisoned at all. The problem of using a longer follow-up period is that the statutory and crime recording landscape has changed so much in recent years that to go further back in time would not be comparable today. The 731-day follow-up will therefore enable examination of what happens in the immediate aftermath of an incident and the medium term, which is important for the purposes of targeting resources.

Issues and Limitations of the Data The variables added to the dataset included offence classification; date and time the incident was reported; and date and time of the incident (Appendix). Demographic details relating to victims and suspects including age at the time of the incident, sex and self-defined ethnicity were also part of the dataset. There were four issues identified with the 192,173 incidents included in the initial dataset which had to be addressed before carrying out any analysis: relationship of suspect to victim, perpetrator details, no crimes and personal crimes, and delayed reports (more than 90 days after event, which were excluded). These details are reported at Barnham (2016: 22-27). The result of these decision processes was a reduction in usable cases of about one quarter. Table 1 presents the final breakdown of the usable data as a proportion of all records during the data collection period.

The final dataset is therefore comprised of a total of 140,998 incidents (Table 2).

\section{Methods}

The question of whether intimate partner abuse escalates over time is analysed below with the following methods. Whether the repeated harm inflicted by perpetrators of partner abuse increases in seriousness over the course of the follow-up period is measured using the Cambridge CHI, with an increased score indicating an escalation in harm. This elevated score can occur in two different ways. Firstly, by a perpetrator committing more serious offences or, secondly, increasing in frequency such that the cumulative score is higher than the first incident in the dataset. If multiple offences took place at the same time, the most serious offence is recorded (as per the NCRS guidelines issued to forces in England and Wales) and the crime harm score for the most serious offence applied. Using the index allows the CHI scores for every

\footnotetext{
The follow-up period is 731 days because dataset includes figures from a leap year in 2012 .

${ }^{3}$ Includes recorded crimes and non-crime incidents. Although it is impossible to charge a non-crime incident, it is pertinent to use the overall number of incidents as the base figure because individuals identified as perpetrators in non-crime incidents will be included in this research.

${ }^{4}$ The Crown Prosecution Service (CPS) is the principal prosecuting authority in England and Wales. They decide every domestic abuse case where a charge is being considered.
} 
Table 1 Total incidents and causes of exclusions

\begin{tabular}{lclc}
\hline Exclusion criteria & $\begin{array}{l}\text { Number of incidents excluded at } \\
\text { each stage }\end{array}$ & $\begin{array}{l}\text { Cumulative number of incident in } \\
\text { data set } \\
192,173\end{array}$ & $\begin{array}{c}\text { Cumulative } \\
\text { No relationship }\end{array}$ \\
$\begin{array}{l}\text { recorded } \\
\text { No perpetrator listed }\end{array}$ & 20,144 & 162,258 & 84.4 \\
Non-personal crime & 54 & 142,144 & 74.0 \\
Non-recent report & 1062 & 142,060 & 73.9 \\
\hline
\end{tabular}

perpetrator of any partner abuse to be tracked across each separate incident in the follow-up period.

The data will be examined in two different ways. Firstly, the top 50, 100 and 500 most harmful perpetrators from 2010 will be identified and their harm scores tracked across the subsequent 5 years of the dataset. Secondly, the first incident for all perpetrators (regardless of harm score) involved in an incident between 1 January 2010 and 31 December 2013 is identified and a fixed 731day follow-up period applied to measure the extent of subsequent crime harm. Using data from the 731-day follow-up, the issue of whether abuse gets worse is also measured by examining how likely perpetrators are to be involved in further incidents using conditional probability analysis as well as how quickly, in days, repeat incidents occur.

Within the context of the 731-day follow-up, conditional probability analysis will be undertaken to explore the conditional probability of incident (B) in relationship to incident (A) where the probability that incident (B) occurs given that incident (A) has already taken place. The probability of (B) given (A) is calculated using the following formula:

$$
P(B \mid A)=\frac{P(A \text { and } B)}{P(A)}
$$

In this research, this method is used to examine the probability of perpetrators being involved in further incidents reported to police.

Table 2 Final number of incidents by year

\begin{tabular}{ll}
\hline Year & Total incidents \\
2010 & 26,824 \\
2011 & 26,961 \\
2012 & 27,496 \\
2013 & 27,829 \\
2014 & 13,662 \\
2015 & 18,226 \\
\hline
\end{tabular}




\section{Findings}

Frequency vs. Harm The incidents which make up the data set for this research include both crime and non-crime incidents between identified intimate partners, reported to Thames Valley Police between 1 January 2010 and 1 January 2016. Figure 1 shows their distribution in volume, by four categories, without any indication of seriousness of the incidents. It shows that non-crime incidents, given a crime harm value of 0.1 days, account for $57 \%$ of the 140,998 incidents of partner abuse.

Non-violent crime accounts for $17 \%$ of all incidents contained within the dataset. Violent crimes make up $25 \%$ while sex crimes account for the smallest proportion of incidents at just $1 \%$. The weight of volume draws the reader's attention to the least serious events.

Figure 2 applies the Cambridge Crime Harm Index to the identical data in Fig. 1, which reveals a strikingly different distribution - drawing the reader's attention to the most serious events.

Figure 2 shows that most of the officially defined crime harm from intimate partner abuse comes from sex crimes, not violent crimes. The sum of 2,248,679 recommended days of imprisonment out of a total of 3,407,372 days of crime harm across all IPV and abuse $(66 \%)$ is accounted for by sex crimes. Despite being high in frequency, noncrime incidents account for only 9173 days of all crime harm $(0.3 \%)$ between 2010 and 2015. Violent incidents represent 807,286 days (24\%) of all harm and non-violent incidents account for 161,573 days $(5 \%)$ of total harm over the research period.

Repeat Offending Of the 140,998 incidents included in the analysis, 52,093 (37\%) were repeat incidents involving the same perpetrator. The other 88,905 incidents include the first time offending of the repeat offenders as well those who offended only once within the period 2010-2015. The majority of all intimate partner incidents in a 6-year period are first offences within that particular couple.

As Fig. 3 shows, the distribution of repeat incidents of intimate partner abuse is very similar to the overall pattern of offending for intimate partner abuse as a whole. Of all repeat incidents between 2010 and 2015, non-crime incidents account for 29,957 incidents out of all 52,093 repeat incidents (58\%). There were 10,856 non-violent

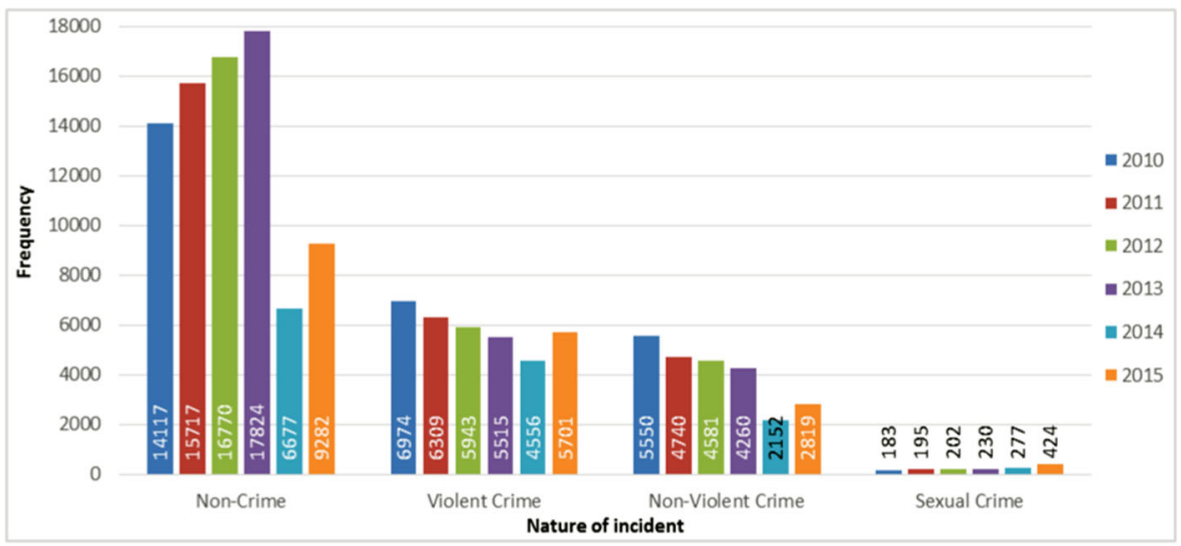

Fig. 1 All incidents 2010-2015 


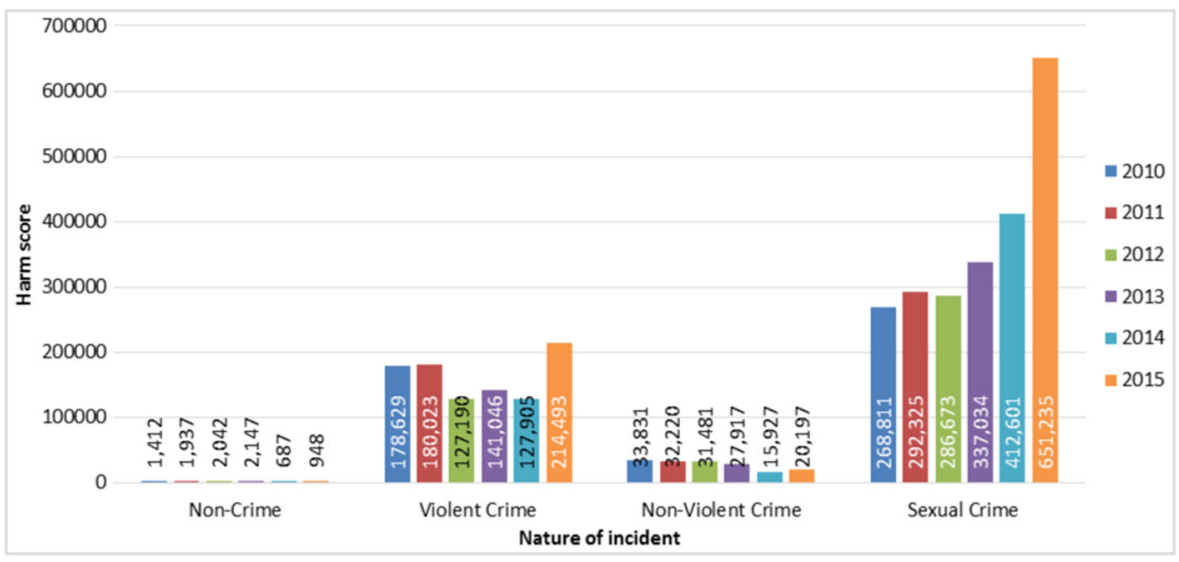

Fig. 2 Crime harm score for all incidents 2010-2015

repeat crimes (21\%) within the data set. Violent repeat crimes total 10,846 (20\%), while sex crimes are again the lowest in number with a total of $434(1 \%)$ repeat crimes being sexual in nature.

The application of the Cambridge $\mathrm{CHI}$ to the repeat cases again shows the contrast between the distribution of frequency and severity of harm. Figure 4 shows the majority of repeat crime harm; 628,032 days out of a total repeat harm score of 1,002,292 $(62.6 \%)$, is accounted for by sex crimes. Non-crime incidents account for just 4132 days of crime harm $(0.4 \%)$ out of the total repeat crime harm score. Violent incidents total 299,154 days of crime harm (30\%) and non-violent incidents account for 70,973 days $(7 \%)$ of total repeat harm over the research period.

Exploring High-Harm Offenders The first method used in this research for identifying whether there is evidence of escalating harm over time is to identify a cohort of high-harm offenders and observe their harm trajectory over time. The procedure used it to track the offending of the top 50,100 and $500^{5}$ perpetrators in 2010 annually through to 2015 . These perpetrators were identified by totalling the crime harm score for each incident an offender was involved in during 2010.

Figure 5 shows the difference in mean crime harm scores between the top 50 and top 100 is $482 \mathrm{CHI}$ days of total recommended imprisonment. The difference between the crime harm amongst the top 100 compared with the top 500 perpetrators is much wider at $1261 \mathrm{CHI}$ days.

Figure 6 shows that amongst the top 50 perpetrators in 2010, the mean harm score was 2596 days in that initial year. In 2011, the mean harm score is still elevated at an average of 323 days, even though it has dropped substantially since 2010 . These results suggest that a small number of high harm perpetrators from 2010 go on to inflict further high harm, although others may have dropped out, gone to prison or left the area. Beyond 2011, the mean crime harm scores fall below 10 days. Similar findings are reported in Barnham (2016: 40-42) for the top 100 and top 500 offenders by CHI total in 2010 .

\footnotetext{
${ }^{5}$ More than one perpetrator held equal 50th and 100th positions with the same crime harm score in 2010. The number of offenders making up the top 50 is 58 and in the top 100 the number is 155 .
} 


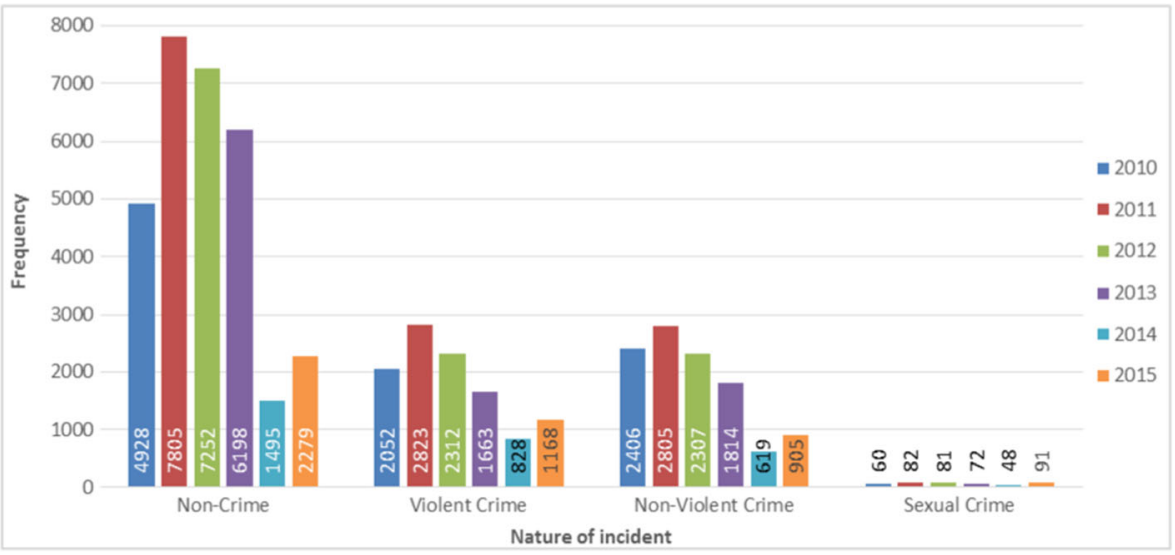

Fig. 3 Repeat incidents 2010-2015

The trends in CHI days per year can be better understood in light of the declining prevalence of intimate partner abuse by the 2010 cohort over time. As Fig. 7 shows, every group of the top CHI offenders in 2010 shows a minority of the group with new offences as early as 2011, with the vast majority disappearing from new reports by 2015. For the most serious IPV offenders, the clear pattern is (officially measured) desistance, not persistence.

Fixed 2-Year Observation Period The second and main method for testing the escalation hypothesis is the 2-year follow-up of 52,296 offenders. Regardless of their crime harm score, this section of the analysis uses a fixed 731-day follow-up period from the point that a perpetrator first appears in the data set between 1 January 2010 and 31 December 2013 to provide further insight into patterns of re-offending. Including only those cases where there was a first incident up to 31 December 2013 enables the consistent application of a fixed 2-year follow-up for every perpetrator in the period covered by the dataset-no more and no less.

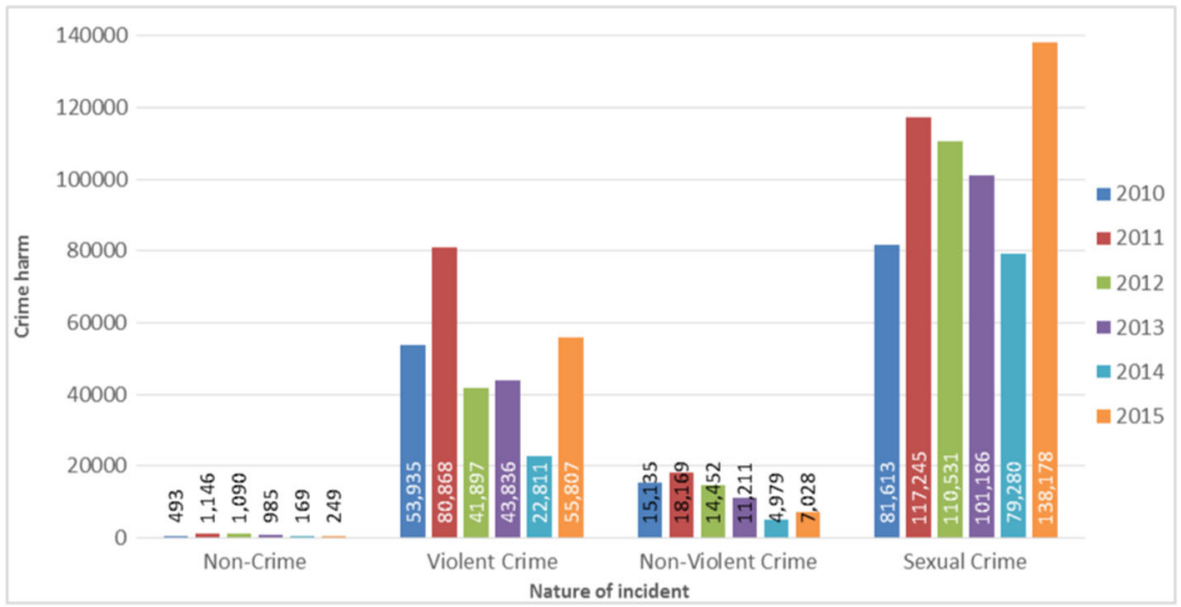

Fig. 4 Crime harm score for repeat incidents 2010-2015 


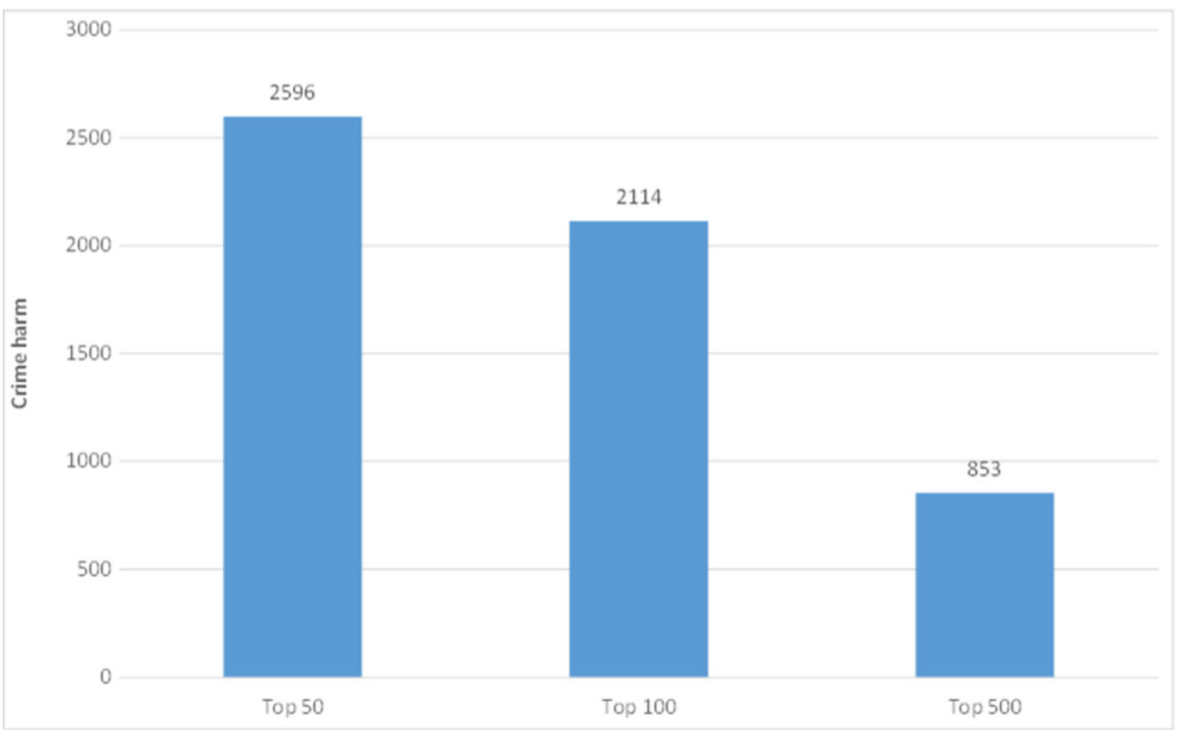

Fig. 5 Mean crime harm scores for top 50, 100 and 500 unique perpetrators in 2010

Incident-Specific Crime Harm Figure 8 displays the CHI scores of all 79,809 incidents involving the 52,296 offenders in the 731-day observation sample. Including the first incident by which they were identified, the majority of the incidents have no repeat offence reported for that couple.

Figure 8 shows a score of 0 to represent single incidents where there was no followup incident, which occurred in $41.5 \%$ of cases. Figure 8 also shows that in $36.1 \%$ of follow-up incidents, the crime harm score was 0.1 . This means that $77.6 \%$ of all incidents within the 731-day follow-up period did not amount to a criminal offence

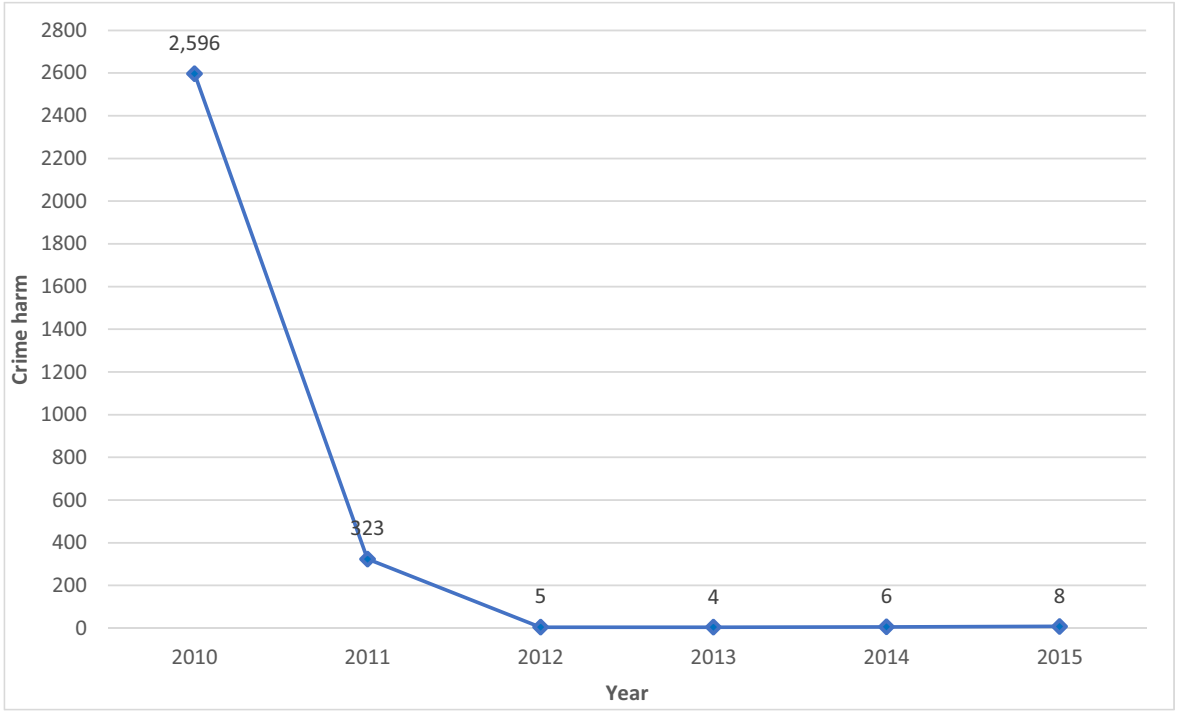

Fig. 6 Mean harm scores for the top 50 unique perpetrators 2010-2015 


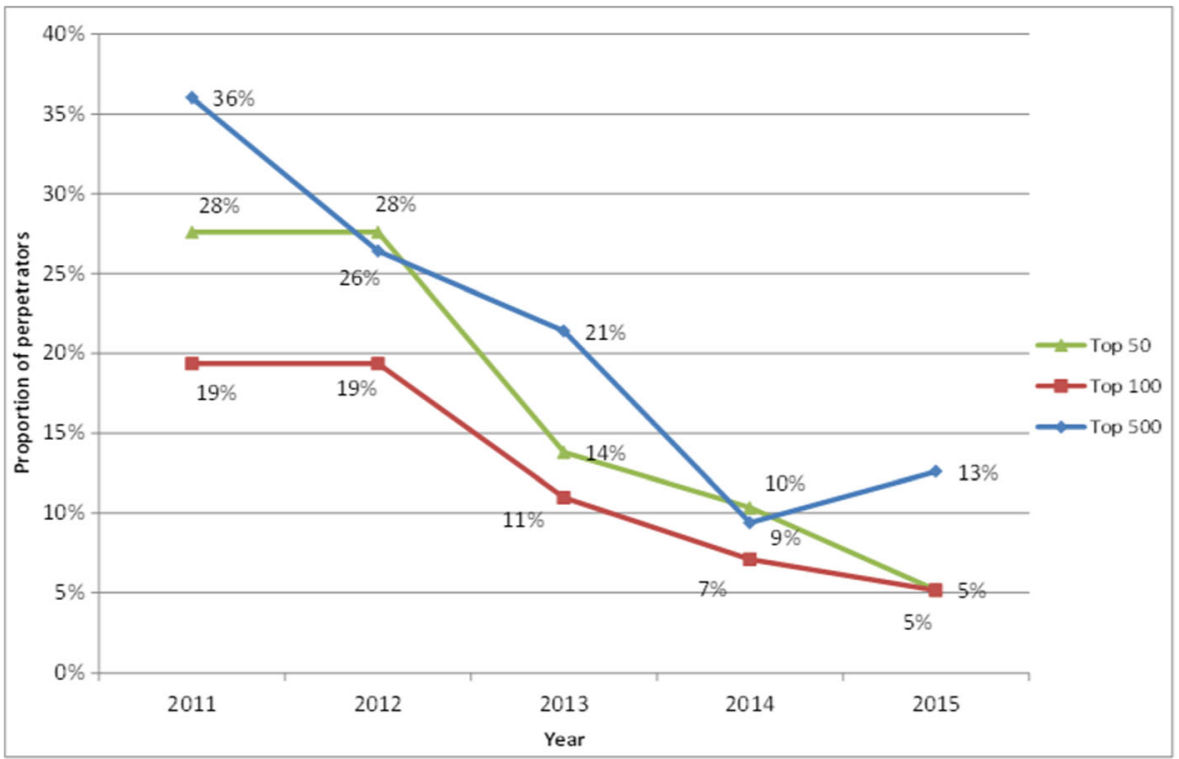

Fig. 7 Proportion of perpetrators from the 2010 cohort who re-offend

at all. A total of $21.2 \%$ of incidents had a harm score between 0.2 and 10 days, leaving a smaller number of higher harm incidents scoring over 10.1 days of crime harm $(n=893)$.

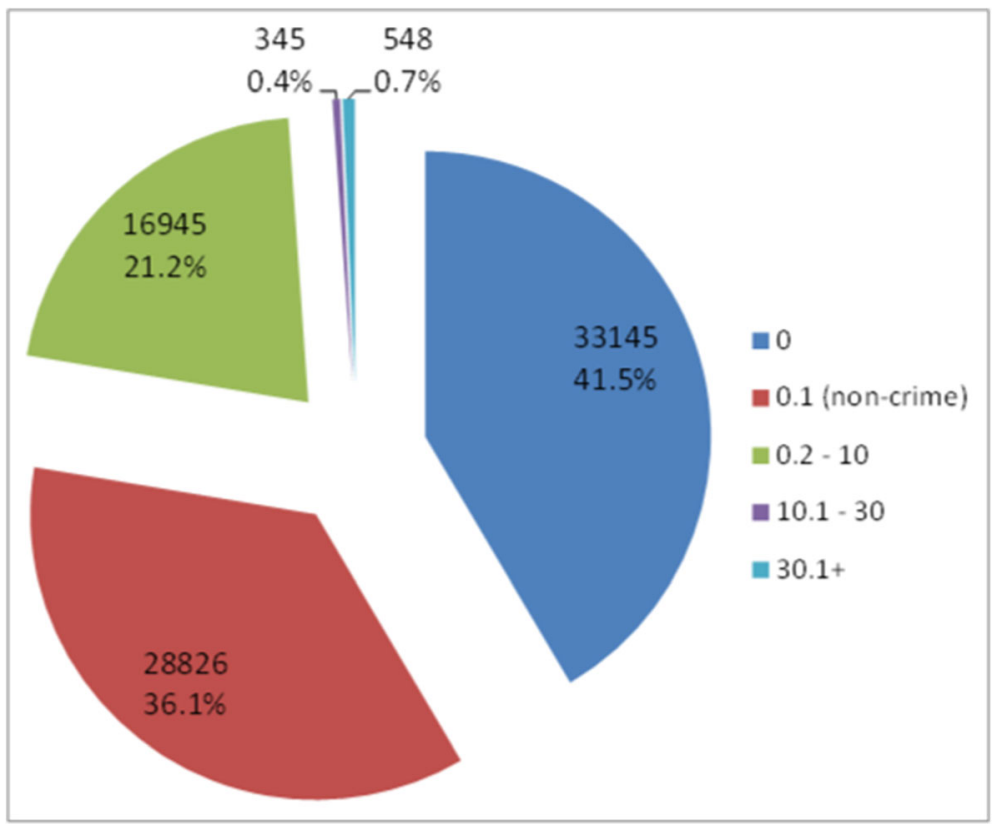

Fig. 8 Incident-based crime harm scores in 2-year follow-up (including first crime harm) 


\section{The Power Few: Concentration of Harm Amongst Unique Perpetrators}

Figure 9 shows the extreme hockey-stick J-shape of a 'Pareto curve' in which a mere $3 \%$ of the offenders produce $90 \%$ of the total CHI total for all 52,296 perpetrators. While there is a small growth of total harm within the top $30 \%$ of offenders, that modest increase over the other $70 \%$ of the group is swamped by the steep rise in the top $10 \%$. Much of this harm, however, may be concentrated at the outset of the period, so it is not clear just how predictable membership in the 'power few' group might be in prospect rather than hindsight.

Repeat Crime Harm Amongst Re-offenders Of these 52,296 unique perpetrators, $19,151(37 \%)$ were involved in a repeat incident in the 731-day follow-up period.

Figure 10 shows that 5786 of the 19,151 perpetrators $(30.2 \%)$ who had a repeat incident were involved in a single non-crime incident over the next 731 days. A further 8525 perpetrators $(44.5 \%)$ have a total harm score of between 0.2 and 10 days in the 2 years after their first incident. A total of 3857 perpetrators $(20.1 \%)$ were responsible for repeat harm that scored 10.1 days or higher. A smaller number of perpetrators, 983 out of $19,151(5.1 \%)$ were responsible for the highest harm totalling over 30.1 days in the follow-up period.

Conditional Probability of Repeat Offending Figure 11 shows that amongst offenders whose first incident was a crime, the probability of a further crime alleged against them generally rises with each further incident (all of which must be crimes to be plotted in this graph).

Figure 11 analyses only those cases where the first and subsequent incidents were crimes (thereby excluding non-crime incidents). The results show that where a crime is recorded, there is a higher probability than in the analysis of all incidents that a

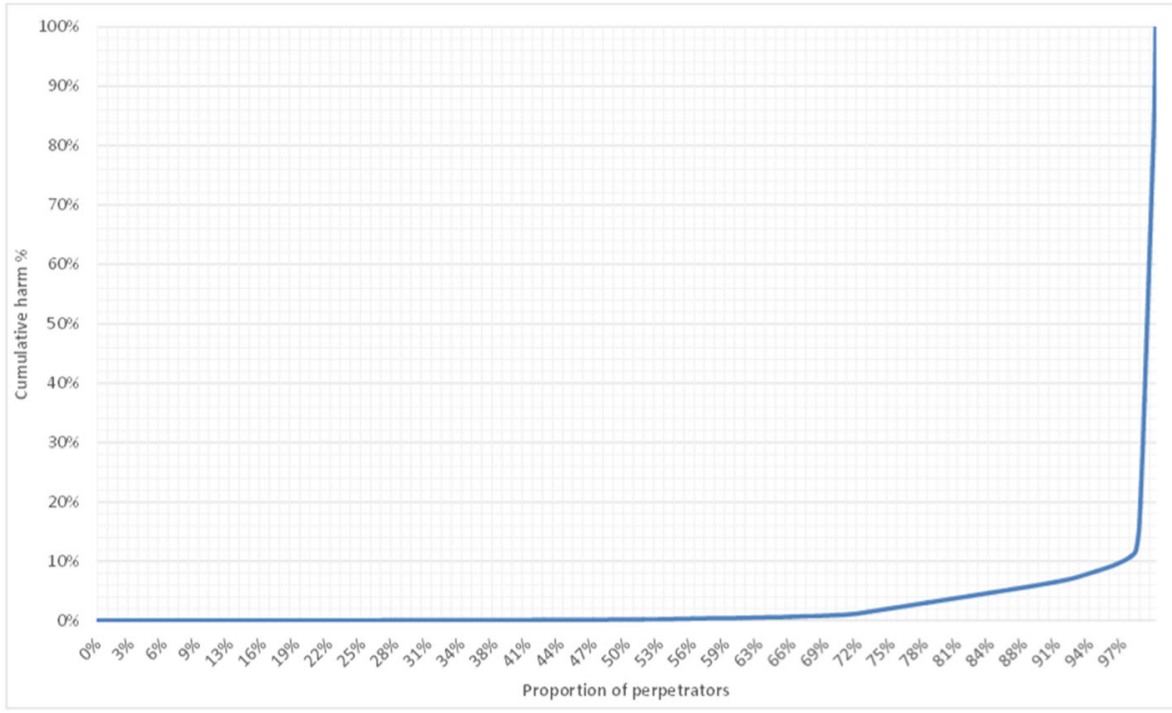

Fig. 9 Cumulative harm: 2-year observation 


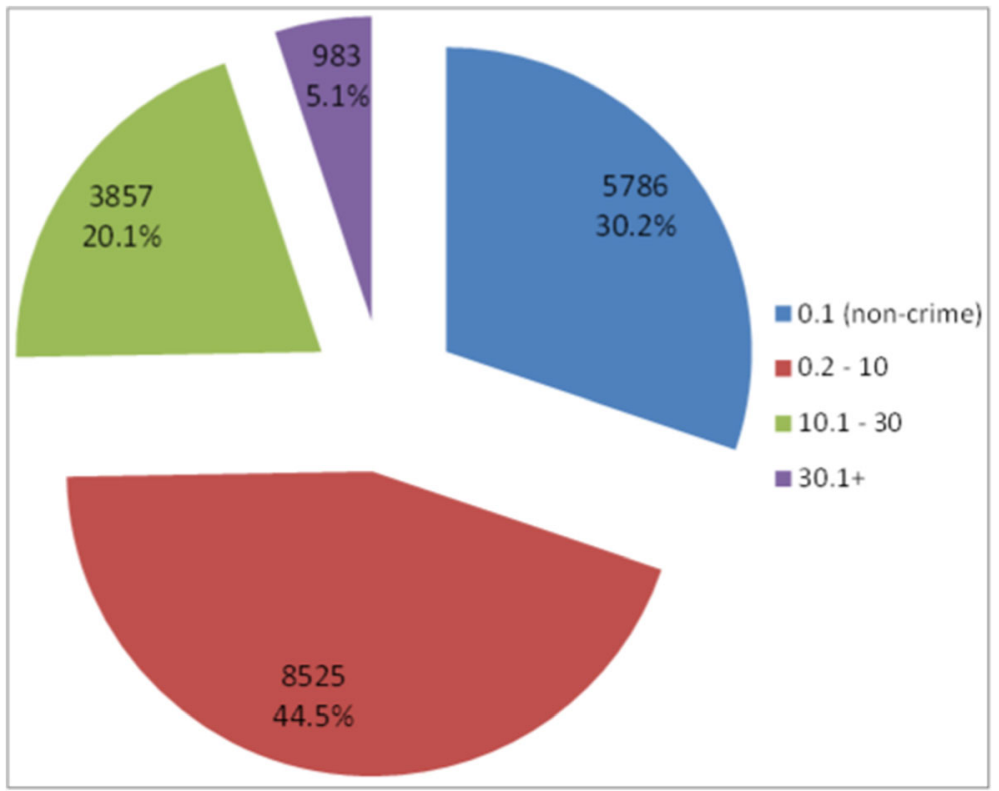

Fig. 10 Perpetrator repeat crime harm scores in 2-year follow-up

perpetrator will go on to be involved in a second crime $(26 \%, n=41,350)$. Again, the likelihood of involvement in further crimes increases as the number of crimes rises. A further crime becomes more likely than not where a perpetrator is involved in a fifth crime $(53 \%, n=795)$. The probability peaks where a perpetrator involved in 14 crimes

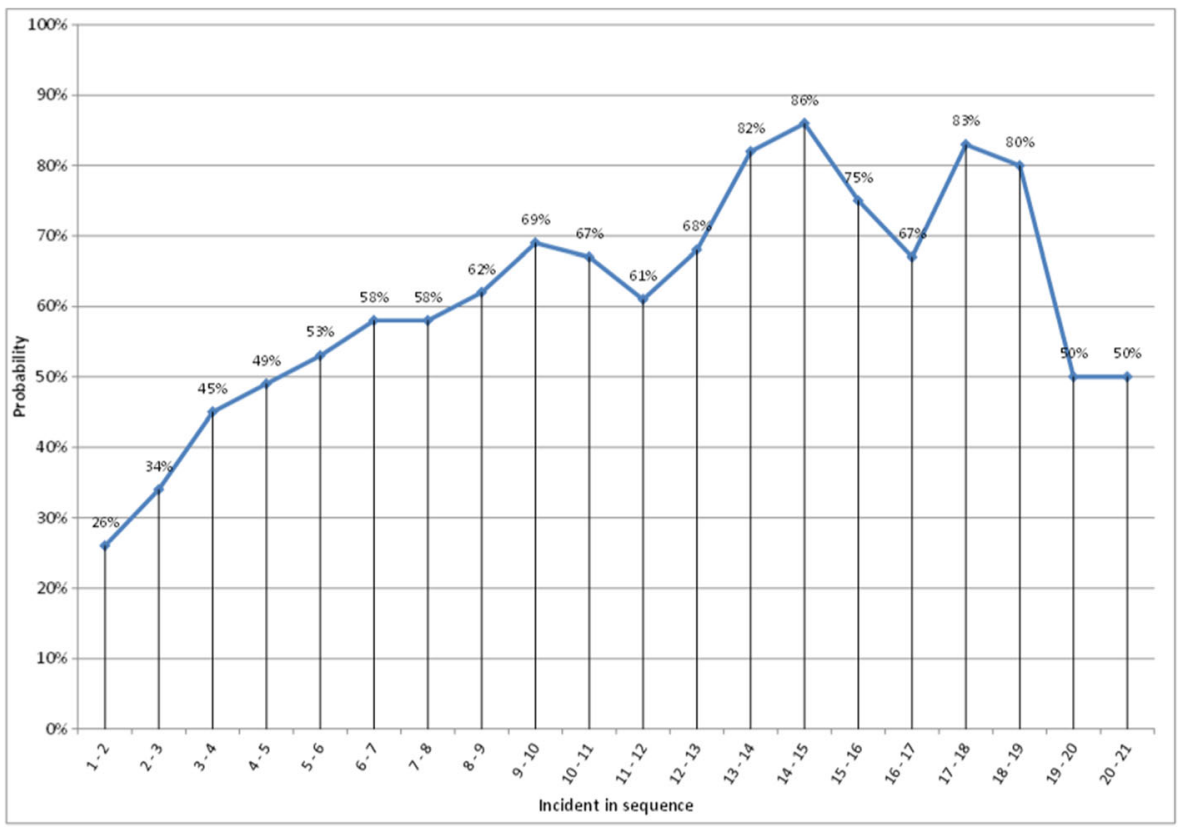

Fig. 11 Conditional probability of repeat domestic crimes 
is $86 \%$ likely to be involved in a 15 th incident. However, at this point in the analysis, there are just two cases with the number of cases falling below 100 between incidents 8 and 9. In summary, the conditional probability for crimes start out higher than when non-crime incidents are also included, but then increase at a slower rate than when crime and non-crime incidents are analysed.

Time Between Repeat Incidents Another aspect of re-offending is the amount of time between further incidents, or frequency within any specified time period.

Figure 12 shows, overall, the average time between incidents gets progressively shorter as the number of incidents increases. The longest mean gap between incidents is between the first and second incidents at an average of 164 days $(n=19,151)$. By incidents $8-9$, the average number of days between incidents falls by $67 \%$ compared with incidents $1-2$ to an average of 55 days $(n=810)$. The shortest average time between incidents is between incidents 19 and 20 with an average of 23 days $(n=59)$.

Escalating Seriousness? Repeat Incident Average Crime Harm Scores Figure 13 shows that for the vast majority of offenders, and even repeat offenders, there is no pattern of escalation in the average $\mathrm{CHI}$ score with each additional repeat offence observed.

While the harm scores remain relatively stable between the second incident (the first repeat) and ninth incident (the eight repeat), they drop at incident ten to an average of 5 days $(n=605)$. At incident 12 , the average harm score falls to 3 days $(n=357)$, but rises to 28 days for incident $14(n=208)$. The average harm score peaks at 33 days for incident 20 , but the number of cases analysed is 59 and may be too small to produce a reliable estimate. It is of note that the number of cases included in the analysis after incident 18 falls below 100 .

These results demonstrate while the probability of a further incident increases and the time between incidents gets shorter as the number of repeat incidents rises, there is little variation in the average harm scores between the second incident and ninth incident. The average harm scores are lower for incidents 10,11, 12 and 13 compared with those for incidents 2-9. Thereafter, the average scores become erratic as the sample sizes get smaller.

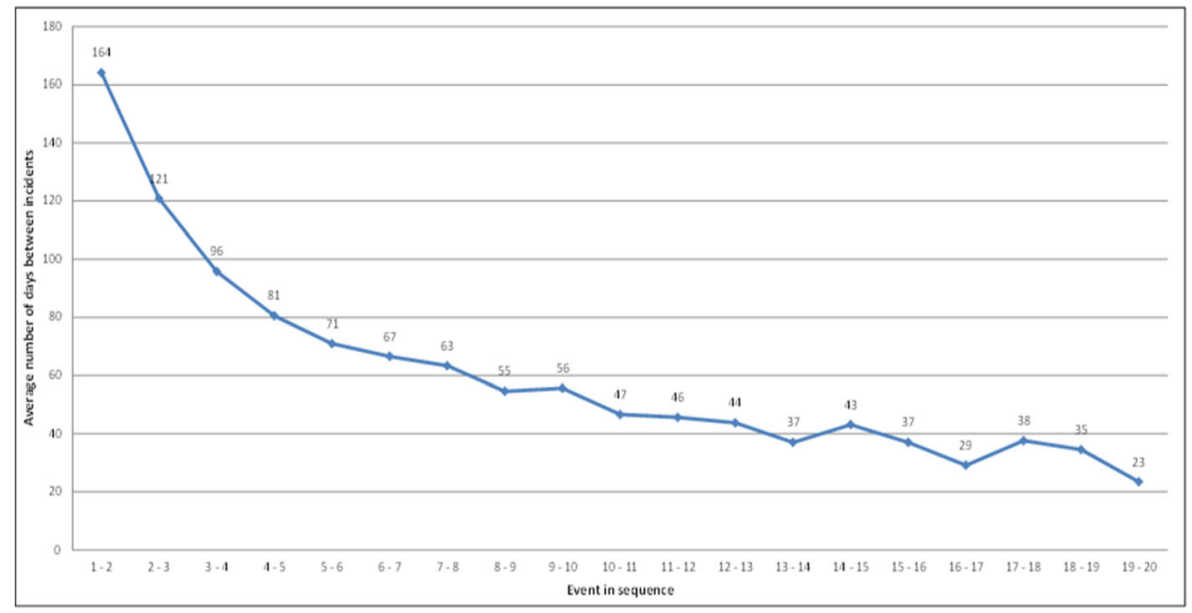

Fig. 12 Average days between incidents 


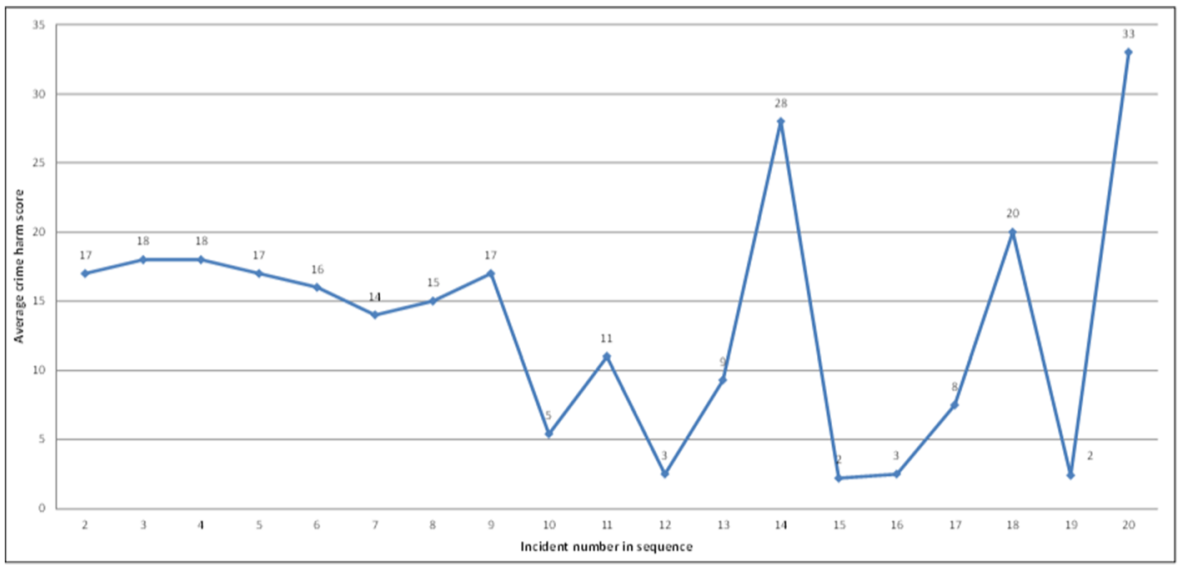

Fig. 13 Average crime harm scores for repeat incidents

\section{Conclusions}

Main Findings This research supports four major conclusions in relation to claims of fact about patterns of intimate partner violence and abuse. First, the perpetrators in most couples who come to police attention in Thames Valley will not go on to commit a future crime against the victim in the next 2 years.

Second, even the most harmful perpetrators drop out of the records of police contact over the next year to 4 years.

Third, in the minority of couples experiencing repeat crime after the initial report, there is no evidence of escalating crime harm severity as measured by the Cambridge Crime Harm Index.

Fourth, while the conditional probability of recurrence of new crimes rises with each additional crime, this has no effect on the seriousness of the crime-i.e. the probability of a new crime escalates, but not the severity. While the pattern of severity is unstable, the average trajectory of harm over repeat incidents is decreasing or flat.

Fifth, while the frequency of repeat crimes may rise with each new incident amongst the minority of couples experiencing repeat police contact, this rise in speed again has no correlation with an increase in harm. Most offences remain at low-harm levels throughout any progression of repeated crimes.

Implications for Policy and Practice in Tackling Partner Abuse This research identifies the presence of a high number of lower harm re-offenders. Indeed, the present research identifies different patterns of re-offending: (1) those who do not re-offend; (2) those whose subsequent involvement with the police is through a non-crime incident; (3) offenders whose follow-up crime harm score was between 0.2 and 10 days and (4) a smaller number who perpetrated more serious abuse totalling over 10.1 days of crime harm. It seems highly relevant to take these patterns into account in refining a resourceallocation protocol across tens of thousands of domestic abuse cases annually.

Research Implications The most ambitious and promising extension of this research would be to use the results to inform the development of a forecasting model using the 
'random forests' statistical method. Although development of this method would require further research in order to identify additional variables and sources of data for inclusion in the prediction model to make predictions, statistically validated forecasts have consistently been shown to be more accurate or at least as good as clinical predictions such as DASH (Barnes and Hyatt 2012; Berk et al. 2009; Sherman 2013).

A model could be built to enable police, as well as other agencies, to identify whether an offender is at high risk (predicted to commit a serious offence), moderate risk (predicted to commit a non-serious offence) or low risk (not predicted to commit any offence) over a particular period of time. Such an approach would provide an opportunity to identify whether there is a risk of repeat offending as well as make a distinction between serious and non-serious harm. If successful, the use of a statistical model could be used by the police to identify risk which would inform the allocation of resources and interventions to provide an output that maximises the safety of victims and reduces false positives and false negatives. More importantly, such an approach would enable police to allocate scarce resources to those offenders most likely to perpetrate further harm.

Acknowledgements We wish to thank the College of Policing and the Policing Knowledge Fund, under the joint administration of the Higher Education Funding Council for England (HEFCE), and the Thames Valley Police for funding this research through a bursary for Lee Barnham to undertake this research as an M.St. thesis for the Cambridge Police Executive Programme. We specifically thank Sara Thornton, formerly Chief Constable of Thames Valley, and current Chief Constable Francis Habgood for their support of this study. Lee Barnham is currently an Inspector assigned to the Emergency Response Team in the High Wycombe area of Thames Valley Police. He spent 5 years working as a Detective Sergeant in the Domestic Abuse Investigation Unit and worked on the implementation of six Multi-Agency Safeguarding Hubs (MASH). This research was originally undertaken as his M.St. thesis for the Cambridge Police Executive Programme at the Cambridge University Institute of Criminology. Dr. Geoffrey Barnes is Director of Criminology for the Western Australia Police in Perth, Australia, and an Affiliated Lecturer in Evidence-Based Policing at the Cambridge University Institute of Criminology. Lawrence W. Sherman is Director of the Cambridge Centre for Evidence-Based Policing, Wolfson Professor of Criminology at the University of Cambridge and Distinguished University Professor at the University of Maryland.

\section{Appendix}

Table 3 Offence classifications and crime harm scores

\begin{tabular}{|c|c|c|c|}
\hline Incident/offence classification & $\begin{array}{l}\text { CHI score } \\
\text { applied }\end{array}$ & $\begin{array}{l}\text { Non-personal } \\
\text { crime }\end{array}$ & $\begin{array}{l}\text { Nature of } \\
\text { incident }\end{array}$ \\
\hline Absent person & 0 & $\mathrm{X}$ & Non-crime \\
\hline Abstract/use without authority electricity & 1 & & Non-violent \\
\hline Abuse of trust & 0 & $\mathrm{X}$ & Non-crime \\
\hline Act of outraging public decency-common law & 10 & & Sexual \\
\hline Act of outraging public decency_-common law & 10 & & Sexual \\
\hline $\begin{array}{l}\text { Administer poison with intent to endanger } \\
\text { life/inflict grievous bodily harm }\end{array}$ & 2190 & & Violent \\
\hline $\begin{array}{l}\text { Administering drugs or using instruments to } \\
\text { procure abortion }\end{array}$ & 1460 & & Violent \\
\hline Adult protection-non-crime occurrence & 0.1 & & Non-crime \\
\hline Adult protection (non-crime incident) & 0.1 & & Non-crime \\
\hline Aggravated burglary_dwelling & 365 & & Non-violent \\
\hline
\end{tabular}


Table 3 (continued)

Incident/offence classification

Aggravated vehicle taking (initial taker) and dangerous driving

Aggravated vehicle taking — vehicle and property damage under $£ 5000$

Aiding suicide

All TEW offences except S10, 78 to 82,92 to 95 Railway Transport Safety Act 2003

Arrange/facilitate travel of a person within the UK for exploitation

Arson-not endangering life

Arson with intent to endanger life

Articles connected to computer misuse

ASB non-crime - medium risk

ASB non-crime related

Assault - S18 - GBH cause grievous bodily harm with intent to resist/prevent arrest

Assault - S18 - GBH grievous bodily harm with intent

Assault-S20-GBH grievous bodily harm without intent

Assault-S39-Common assault

Assault — S47-AOABH assault occasioning actual bodily harm

Assault of a person assisting a constable ( $\mathrm{Sec} 38$ )

Assault on constable police act 1996

Assault with injury

Assault with intent to commit robbery-business

Assault without injury on constable

Assaults an officer of Revenue or Customs

Attempt murder - victim aged 1 year or over

Bail offences

Bigamy

Blackmail

Bomb hoax - communicate false information

Breach a non-molestation order-Family Law Act 1996

Breach licence requirement contravention S161

Breach of a Restraining Order issued on acquittal

Breach of an anti-social behaviour order

Breach of criminal behaviour order

Breach of sex offender order

Bring/throw/convey a list 'A' prohibited article into/out of a prison-Prison Act 1952

Burglary dwelling - distraction with intent to steal
1460

CHI score applied

126

10

182.5

18.75

2190

\section{2}

0

0

1460

1460

18.75

1

10

$\begin{array}{ll}\begin{array}{l}\text { Non-personal } \\ \text { crime }\end{array} & \begin{array}{l}\text { Nature of } \\ \text { incident }\end{array}\end{array}$

Non-violent

Non-violent

Violent

Non-violent

Sexual

Violent

Violent

Non-violent

Non-crime

Non-crime

Violent

Violent

Violent

Violent

Violent

Non-crime

Non-crime

Violent

Violent

Non-crime

Non-crime

Violent

Non-violent

Non-violent

Non-violent

Non-violent

Non-violent

Non-crime

Non-violent

Non-violent

Non-violent

Non-violent

Non-violent

Non-violent 
Table 3 (continued)

\begin{tabular}{|c|c|c|c|}
\hline Incident/offence classification & $\begin{array}{l}\text { CHI score } \\
\text { applied }\end{array}$ & $\begin{array}{l}\text { Non-personal } \\
\text { crime }\end{array}$ & $\begin{array}{l}\text { Nature of } \\
\text { incident }\end{array}$ \\
\hline Burglary dwelling — stealing & 18.75 & & Non-violent \\
\hline Burglary dwelling — with intent to steal & 18.75 & & Non-violent \\
\hline Burglary non dwelling - theft only & 10 & & Non-violent \\
\hline $\begin{array}{l}\text { Burglary non dwelling - with intent to commit } \\
\text { or with the commission of an offence }\end{array}$ & 10 & & Non-violent \\
\hline $\begin{array}{l}\text { Burglary non dwelling (attempts only)—with } \\
\text { intent to steal }\end{array}$ & 10 & & Non-violent \\
\hline $\begin{array}{l}\text { Burglary other than dwelling - with intent to } \\
\text { inflict GBH }\end{array}$ & 730 & & Violent \\
\hline Burglary other than in a dwelling (attempts only) & 10 & & Non-violent \\
\hline $\begin{array}{l}\text { Burglary other than in a dwelling (excluding } \\
\text { attempts) }\end{array}$ & 10 & & Non-violent \\
\hline $\begin{array}{l}\text { Care worker ill-treat/wilfully neglect an } \\
\text { individual }\end{array}$ & 84 & & Non-violent \\
\hline $\begin{array}{l}\text { Cause administer poison with intent to } \\
\text { injure/aggrieve/annoy }\end{array}$ & 182.5 & & Violent \\
\hline Cause bodily harm by wanton/furious driving & 10 & & Violent \\
\hline Causing danger to road users & 1.5 & & Non-violent \\
\hline Causing serious injury by dangerous driving & 547.5 & & Violent \\
\hline Child abduction — other person & 548 & & Non-violent \\
\hline Child abduction-parent & 273 & & Non-violent \\
\hline Child destruction & 365 & & Violent \\
\hline Child protection (non-crime incident) & 0.1 & & Non-crime \\
\hline Conspire to murder & 1460 & & Violent \\
\hline Contaminate/interfere with goods & 18.75 & & Violent \\
\hline Contempt of court & 0 & $\mathrm{X}$ & Non-crime \\
\hline Criminal damage & 2 & & Non-violent \\
\hline Criminal damage other-value over $£ 5000$ & 84 & & Non-violent \\
\hline Criminal damage other-value under $£ 5000$ & 2 & & Non-violent \\
\hline Criminal damage to a building other than a dwelling & 2 & & Non-violent \\
\hline $\begin{array}{l}\text { Criminal damage to a building other than a } \\
\text { dwelling _ endangering life }\end{array}$ & 730 & & Violent \\
\hline Criminal damage to a dwelling & 2 & & Non-violent \\
\hline Criminal damage to a dwelling — endangering life & 730 & & Violent \\
\hline Criminal damage to a dwelling — value over $£ 5000$ & 84 & & Non-violent \\
\hline Criminal damage to a vehicle — value over $£ 5000$ & 84 & & Non-violent \\
\hline Criminal damage to a vehicle — value under $£ 5000$ & 2 & & Non-violent \\
\hline Disablist incident (non-recordable crime) & 0.1 & & Non-crime \\
\hline $\begin{array}{l}\text { Disclose private sexual images to cause distress } \\
\text { (incl. photos/films) }\end{array}$ & 10 & & Non-violent \\
\hline Disclosure scheme - non-crime occurrence & 0 & $\mathrm{X}$ & Non-crime \\
\hline $\begin{array}{l}\text { Distribute an indecent } \\
\text { photograph/pseudo-photograph of a child }\end{array}$ & 91 & & Sexual \\
\hline Do an act which harmed a witness/juror & 126 & & Violent \\
\hline
\end{tabular}


Table 3 (continued)

\begin{tabular}{|c|c|c|c|}
\hline Incident/offence classification & $\begin{array}{l}\text { CHI score } \\
\text { applied }\end{array}$ & $\begin{array}{l}\text { Non-personal } \\
\text { crime }\end{array}$ & $\begin{array}{l}\text { Nature of } \\
\text { incident }\end{array}$ \\
\hline Dog causing injury in a private place & 2 & & Non-violent \\
\hline Domestic incident (non-crime incident) & 0.1 & & Non-crime \\
\hline Drive a motor vehicle dangerously & 10 & & Non-violent \\
\hline Drug possession-cannabis & 0 & $\mathrm{X}$ & Non-crime \\
\hline Drug possession-excluding cannabis & 0 & $\mathrm{X}$ & Non-crime \\
\hline $\begin{array}{l}\text { Drug supplying (Incl. possession W/I to } \\
\text { supply)/production/cultivation }\end{array}$ & 0 & $\mathrm{X}$ & Non-crime \\
\hline Drugs wef $26 / 1 / 09$ possession of cannabis class B & 0 & $\mathrm{X}$ & Non-crime \\
\hline Drugs wef 26/1/09 production of cannabis class B & 0 & $\mathrm{X}$ & Non-crime \\
\hline $\begin{array}{l}\text { Engage in controlling/coercive behaviour in an } \\
\text { intimate/family relationship }\end{array}$ & 182.5 & & Non-violent \\
\hline Failure to comply with regulations & 0 & $\mathrm{X}$ & Non-crime \\
\hline False imprisonment-common law & 548 & & Violent \\
\hline False oral/written unsworn statement & 91 & & Non-violent \\
\hline $\begin{array}{l}\text { Firearms - firearm-possession with intent to } \\
\text { cause fear of violence }\end{array}$ & 1825 & & Violent \\
\hline $\begin{array}{l}\text { Firearms - possess imitation } \\
\text { firearm - committing schedule } 1 \text { offence }\end{array}$ & 1095 & & Violent \\
\hline $\begin{array}{l}\text { Firearms - possession of imitation firearm with } \\
\text { intent to cause fear of violence }\end{array}$ & 1825 & & Violent \\
\hline Forced marriage offences & 548 & & Non-violent \\
\hline Fraud by abuse of position—Fraud Act 2006 & 252 & & Non-violent \\
\hline $\begin{array}{l}\text { Fraud by false representation-cheque, card and } \\
\text { online banking }\end{array}$ & 10 & & Non-violent \\
\hline Fraud by false representation —other methods & 10 & & Non-violent \\
\hline $\begin{array}{l}\text { Handling controlled waste without reasonable } \\
\text { measure }\end{array}$ & 0 & $\mathrm{X}$ & Non-crime \\
\hline $\begin{array}{l}\text { Harassment (first single incident) non-recordable } \\
\text { crime }\end{array}$ & 0.1 & & Non-violent \\
\hline Harassment etc. of a person in his home & 5 & & Non-violent \\
\hline Hold person in slavery or servitude & 365 & & Violent \\
\hline Honour-based violence — non-recordable crime & 0.1 & & Non-crime \\
\hline Immigration offences & 0 & $\mathrm{X}$ & Non-crime \\
\hline $\begin{array}{l}\text { Interfere with a motor } \\
\text { vehicle/trailer/cycle-endanger road user }\end{array}$ & 3 & & Non-violent \\
\hline Intimidate a witness/juror & 42 & & Non-violent \\
\hline Kidnap-common law & 548 & & Violent \\
\hline Linked investigation & 0 & $X$ & Non-crime \\
\hline Make/cause/permit display of indecent matter & 91 & & Non-violent \\
\hline $\begin{array}{l}\text { Make indecent photograph/pseudo-photograph } \\
\text { of a child }\end{array}$ & 547.5 & & Sexual \\
\hline Manslaughter & 1095 & & Violent \\
\hline Missing person & 0 & $\mathrm{X}$ & Non-crime \\
\hline Murder-victim 1 year of age or older & 5475 & & Violent \\
\hline
\end{tabular}


Table 3 (continued)

Incident/offence classification
N100_reported rape: credible evidence to the
contrary exists
N100_reported rape: victim (or 3rd party acting
on their behalf) has not confirmed the offence
or cannot be traced

Notifiable offences not classified elsewhere

CHI score
applied

0

0

10

Obstruct the course of public justice-Common Law

Other burglary in a building other than a dwelling

Other criminal damage

Perjury

Person who provides immigration advice or services in contravention with legislation or restraining order

Possess an offensive weapon

Possession of a controlled drug GBL/14BD

Proceeds of crime - conceal/disguised/converted/transferred/removed criminal property

Procuring illegal abortion

Public health offences (historic)

Public nuisance - common law

Public order-S2 harassment without violence

Public order-S2 violent disorder

Public order - S3 affray

Public order — S3 harassment — breach of civil injunction

Public order-S4 harassment-put in fear of violence

Public order-S4A words/behaviour to cause harassment/alarm/distress

Public order-S5 harassment — breach of restraining order

Public order - S5 use threatening words/behaviour to cause harassment alarm or distress

Publish an obscene article

Racially/religiously aggravated assault occasioning $\mathrm{ABH}$

Racially/religiously aggravated common assault

Racially/religiously aggravated harassment/alarm/distress

Racially/religiously aggravated harassment with fear of violence

Racially/religiously aggravated wounding/GBH without intent

Racist incident (non-recordable crime)

$\begin{array}{ll}\begin{array}{l}\text { Non-personal } \\ \text { crime }\end{array} & \begin{array}{l}\text { Nature of } \\ \text { incident } \\ \text { X }\end{array} \\ \text { Non-crime }\end{array}$

Non-crime

Non-violent

Non-violent

Non-violent

Non-violent

Non-crime

Violent

Non-crime

Non-violent

Violent

Non-crime

Non-violent

Non-violent

Violent

Violent

Non-violent

Violent

Non-violent

Non-violent

Non-crime

Sexual

Violent

Violent

Non-violent

Violent

Violent

Non-crime 
Table 3 (continued)

\begin{tabular}{|c|c|c|c|}
\hline Incident/offence classification & $\begin{array}{l}\text { CHI score } \\
\text { applied }\end{array}$ & $\begin{array}{l}\text { Non-personal } \\
\text { crime }\end{array}$ & $\begin{array}{l}\text { Nature of } \\
\text { incident }\end{array}$ \\
\hline $\begin{array}{l}\text { Resisting or wilfully obstructing a designated or } \\
\text { accredited person in the execution of their duty }\end{array}$ & 0 & $\mathrm{X}$ & Non-crime \\
\hline Road traffic (non-crime incident) & 0 & $\mathrm{X}$ & Non-crime \\
\hline Robbery & 365 & & Violent \\
\hline $\begin{array}{l}\text { Section } 136 \text { Mental Health Act-non-crime } \\
\text { incident }\end{array}$ & 0 & $\mathrm{X}$ & Non-crime \\
\hline $\begin{array}{l}\text { Sending letters etc. with intent to cause distress } \\
\text { or anxiety (Malicious Comms Act) }\end{array}$ & 10 & & Non-violent \\
\hline $\begin{array}{l}\text { Sex — administer a substance with intent — SOA } \\
2003\end{array}$ & 730 & & Sexual \\
\hline $\begin{array}{l}\text { Sex — adult abuse of position of } \\
\text { trust—cause/incite sexual activity with boy } \\
\text { 13-17-SOA } 2003\end{array}$ & 10 & & Sexual \\
\hline $\begin{array}{l}\text { Sex - adult abuse position of trust — cause child } \\
13-17 \text { watch a sexual act-SOA } 2003\end{array}$ & 10 & & Sexual \\
\hline $\begin{array}{l}\text { Sex — adult incite sexual activity with a boy } \\
\text { under } 13 \text { family } \\
\text { member-penetration-SOA } 2003\end{array}$ & 2190 & & Sexual \\
\hline $\begin{array}{l}\text { Sex-adult incite sexual activity with a family } \\
\text { member-victim girl } 13 \text { to } 17 \text { - no } \\
\text { penetration-SOA } 2003\end{array}$ & 10 & & Sexual \\
\hline $\begin{array}{l}\text { Sex - adult incite sexual activity with a family } \\
\text { member-victim girl } 13 \text { to } \\
\text { 17-penetration-SOA } 2003\end{array}$ & 1277.5 & & Sexual \\
\hline $\begin{array}{l}\text { Sex - adult meet girl under } 16 \text { following sexual } \\
\text { grooming_-SOA } 2003\end{array}$ & 547.5 & & Sexual \\
\hline $\begin{array}{l}\text { Sex - adult sexual activity with a girl } 13-17 \\
\text { family member-penetration-SOA } 2003\end{array}$ & 1277.5 & & Sexual \\
\hline $\begin{array}{l}\text { Sex - adult sexual activity with a girl under } 13 \\
\text { family member-no penetration-SOA } 2003\end{array}$ & 10 & & Sexual \\
\hline $\begin{array}{l}\text { Sex - assault a boy under } 13 \text { by penetration with } \\
\text { a part of your body/a thing-SOA } 2003\end{array}$ & 1460 & & Sexual \\
\hline $\begin{array}{l}\text { Sex — assault a boy under } 13 \text { by touching — SOA } \\
2003\end{array}$ & 182 & & Sexual \\
\hline $\begin{array}{l}\text { Sex-assault a girl under } 13 \text { by penetration with } \\
\text { a part of your body/a thing-SOA } 2003\end{array}$ & 1460 & & Sexual \\
\hline $\begin{array}{l}\text { Sex-assault a girl under } 13 \text { by touching — SOA } \\
2003\end{array}$ & 182 & & Sexual \\
\hline $\begin{array}{l}\text { Sex-attempt to rape a woman } 16 \text { or } \\
\text { over-SOA } 2003\end{array}$ & 1825 & & Sexual \\
\hline Sex-attempted rape of a female under 16 & 1825 & & Sexual \\
\hline $\begin{array}{l}\text { Sex — care worker cause/incite sexual activity } \\
\text { with mental disordered } \\
\text { person-penetration-SOA } 2003\end{array}$ & 1825 & & Sexual \\
\hline $\begin{array}{l}\text { Sex - care worker cause/incite sexual activity } \\
\text { with mentally disordered person-no } \\
\text { penetration-SOA } 2003\end{array}$ & 182 & & Sexual \\
\hline
\end{tabular}


Table 3 (continued)

Incident/offence classification
Sex — care worker engage in sexual activity with
mentally disordered male — no
penetration — SOA 2003
Sex — cause/allow sexual penetration per
vagina/anus of a female person by a living
animal-SOA 2003
Sex - cause a female 13 or over to engage in a
non-penetrative sexual activity-SOA 2003
Sex-cause a female 13 or over to engage in a
penetrative sexual activity-SOA 2003
Sex-cause a male 13 or over to engage in a
penetrative sexual activity-SOA 2003
Sex-exposure-SOA 2003
Sex-offender 18 or over cause a child under 13
to watch/look at an image of sexual
activity-SOA 2003

Sex - rape a boy under 13-SOA $2003 \quad 1825$

$\begin{array}{lll}\begin{array}{l}\text { CHI score } \\ \text { applied }\end{array} & \begin{array}{l}\text { Non-personal } \\ \text { crime }\end{array} & \begin{array}{l}\text { Nature of } \\ \text { incident }\end{array} \\ 182 & & \text { Sexual }\end{array}$

Sexual

Sexual

Sexual

Sexual

Sexual

Sexual

Sex — rape a girl aged 13/14/15—SOA 2003

Sexual

Sex — rape a girl under 13-SOA 2003

Sexual

Sex - rape a male under 16

Sexual

Sex - rape a man 16 or over-SOA 2003

Sexual

Sex - rape a woman 16 years of age or

Sexual over-SOA 2003

Sex - sexual assault on a female-SOA 2003

Sexual

Sex-sexual assault on a male-SOA 2003

Sexual

Sex - solicit a person or persons for the purposes

Sexual of prostitution in a public place

Sex - trafficking persons into the UK for sexual exploitation-SOA 2003

Sex - voyeurism - recording a private act-SOA 2003

Sex activity with a female child under 16 no penetration offender under 18

Sex activity with a female child under 16 penetration offender under 18

Sex activity with a male child under 13 no penetration offender under 18

Shoplifting

Stalking - involving fear of violence

Sexual

Stalking_involving serious alarm/distress

Stalking_pursue a course of conduct

Supply or offering to supply a controlled drug other class A

Suspected case-non-crime incident

Sexual

Sexual

Sexual

Take a conveyance (not motor vehicle/pedal cycle) without consent

Non-crime

Violent

Non-violent

Non-violent

Non-violent

Non-crime

Non-violent 
Table 3 (continued)

\begin{tabular}{|c|c|c|c|}
\hline Incident/offence classification & $\begin{array}{l}\text { CHI score } \\
\text { applied }\end{array}$ & $\begin{array}{l}\text { Non-personal } \\
\text { crime }\end{array}$ & $\begin{array}{l}\text { Nature of } \\
\text { incident }\end{array}$ \\
\hline $\begin{array}{l}\text { Take a motor vehicle without the owner's } \\
\text { consent }\end{array}$ & 5 & & Non-violent \\
\hline Taking a pedal cycle without consent & 2 & & Non-violent \\
\hline Theft — other - including theft by finding & 2 & & Non-violent \\
\hline Theft by employee & 5 & & Non-violent \\
\hline Theft from meter or automatic machine & 2 & & Non-violent \\
\hline Theft from motor vehicle & 2 & & Non-violent \\
\hline Theft from the person of another & 2 & & Non-violent \\
\hline $\begin{array}{l}\text { Theft in dwelling other than auto machine or } \\
\text { meter }\end{array}$ & 2 & & Non-violent \\
\hline $\begin{array}{l}\text { Theft of conveyance other than motor vehicle or } \\
\text { pedal cycle }\end{array}$ & 2 & & Non-violent \\
\hline Theft of mail bag/postal packet & 2 & & Non-violent \\
\hline Theft of motor vehicle & 5 & & Non-violent \\
\hline Theft of pedal cycle & 2 & & Non-violent \\
\hline $\begin{array}{l}\text { Threaten with an offensive weapon in a public } \\
\text { place }\end{array}$ & 182.5 & & Violent \\
\hline Threats to kill & 10 & & Violent \\
\hline Unexplained death (CRI) & 0 & $\mathrm{X}$ & Non-crime \\
\hline Unlawful harassment of occupier & 5 & & Non-violent \\
\hline $\begin{array}{l}\text { Use of noxious substances or things to cause } \\
\text { harm and intimidate }\end{array}$ & 182.5 & & Violent \\
\hline Vehicle interference-motor vehicle & 3 & & Non-violent \\
\hline Warrants management & 0 & $\mathrm{X}$ & Non-crime \\
\hline Wasting police time PND_- CRI & 0 & $\mathrm{X}$ & Non-crime \\
\hline
\end{tabular}

Open Access This article is distributed under the terms of the Creative Commons Attribution 4.0 International License (http://creativecommons.org/licenses/by/4.0/), which permits unrestricted use, distribution, and reproduction in any medium, provided you give appropriate credit to the original author(s) and the source, provide a link to the Creative Commons license, and indicate if changes were made.

\section{References}

Barnes, G. C., \& Hyatt, J. M. (2012). Classifying adult probationers by forecasting future offending: final technical report, United States Department of Justice.

Barnham, L. (2016). Targeting perpetrators of partner abuse in the Thames Valley: A two-year follow up of crime harm and escalation. M.St. Thesis, Police Executive Programme, Institute of Criminology, University of Cambridge.

Berk, R., Sherman, L. W., Barnes, G. C., Kurtz, E., \& Ahlman, L. (2009). Forecasting murder within a population of probationers and parolees: a high stakes application of statistical learning. Journal of the Royal Statistical Society, 172(part 1), 191-211.

Bland, M., \& Ariel, B. (2015). Targeting escalation in reported domestic abuse: evidence from 36,000 callouts. International Criminal Justice Review, 25(1), 30-53. 
Crown Prosecution Service (2016). CPS domestic abuse prosecution outcomes 2008-2015, [Online] accessed $27^{\text {th }}$ July 2016. Available from: https://data.gov.uk/dataset/crown-prosecution-service-violence-againstwomen-and-girls-annual-report-2014-2015-data/resource/0eb4d50c-b172-4d16-83dd-8e6ebc9dd04e.

Dubourg, R., \& Hamed, J. (2005). Estimates of the economic and social costs of crime in England and Wales: costs of crime against individuals and households, 2003/04, [Online] Home Office Online Report 30/05 accessed $2^{\text {nd }}$ April 2016. Available from: http://webarchive.nationalarchives.gov.uk/20100413151441 /http:/www.homeoffice.gov.uk/rds/pdfs05/rdsolr3005.pdf.

Hanson, R. K., Harris, A. J. R., Helmus, L., \& Thornton, D. (2014). High-risk sex offenders' may not be high risk forever. Journal of Interpersonal Violence, 29(15), 2792-2813.

Her Majesty's Inspectorate of Constabulary (2014). Everyone's business: improving police response to domestic abuse, [Online] accessed $11^{\text {th }}$ April 2016. Available from http://www.hmic.gov. uk/publication/improving-the-police-response-to-domestic-abuse/.

Home Office (2013). Find out about domestic violence and abuse, coercive control, disclosure scheme, protection notices, domestic homicide reviews and advisers, [Online] accessed $11^{\text {th }}$ April 2016. Available from https:/www.gov.uk/guidance/domestic-violence-and-abuse\%23domestic-violence-and-abuse-newdefinition.

Ignatans, D., \& Pease, K. (2016). Taking crime seriously: playing the weighting game. Policing, 10(3), 184-193.

ONS (UK Office of National Statistics) (2016). Research Outputs: Developing a CrimeSeverity Score for England and Wales Using Data on Crimes Recorded by the Police. London: ONS, 30 November.

Pagelow, M. D. (1981). Woman battering: victims and their experiences. Beverley Hills: Sage.

Piquero, A. R., Brame, R., Fagan, J., \& Moffitt, T. E. (2006). Assessing the offending activity of criminal domestic violence suspects: offense specialization, escalation, and de-escalation evidence from the Spouse Assault Replication Program. Public Health Reports, 121(4), 409-418.

Ratcliffe, JH (2015). Towards an index for harm-focused policing. Policing: A Journal of Policy and Practice. $9(2), 164-182$

Richards, L., Lethcford, S., \& Stratton, S. (2008). Policing domestic violence. Oxford: Oxford University Press.

Sellin, T., \& Wolfgang, M. E. (1964). The measurement of delinquency. New York: Wiley.

Sherman, L. W. (2007). The power few: experimental criminology and the reduction of harm. Journal of Experimental Criminology, 3, 299-321.

Sherman, L. W. (2013). The rise of evidence-based policing: targeting, testing and tracking. Chicago: The University of Chicago.

Sherman LW, Neyroud P, \& Neyroud EC (2014). The Cambridge Crime Harm Index (CHI): Measuring total harm from crime based on sentencing guidelines. Version 2.0. Unpublished Report, Institute of Criminology, University of Cambridge.

Sherman, L. W., Neyroud, P., \& Neyroud, E. (2016). The Cambridge Crime Harm Index (CHI): measuring total harm from crime based on sentencing guidelines. Policing, 10(3), 171-183.

Strang, Heather, Neyroud, Peter \& Sherman, Lawrence, '(2014). 'Tracking the Evidence for a "Mythical Number": Do UK Domestic Abuse Victims Suffer an Average of 35 Assaults Before Someone Calls the Police?' Policing: A Journal of Policy and Practice. doi:10.1093/police/pau016

Walker, L. E. A. (2006). Battered woman syndrome: empirical findings. Annals New York Academy of Sciences, 1087, 142-157.

Wallace, M., Turner, J., Matarazzo, A., \& Babyak, C. (2009). Measuring crime in Canada: introducing the crime severity index and improvements to the Uniform Crime Reporting Survey', Catalogue No. 85-004$X$. Ottawa: Minister of Industry, Statistics Canada.

Wolfgang, M. E., Figlio, R. M., Tracy, P. E., \& Singer, S. I. (1985). The national survey of crime severity. Washington DC: US Department of Justice, Bureau of Justice Statistics. 